\begin{tabular}{|c|c|c|c|}
\hline$D E$ & \multirow{3}{*}{$\begin{array}{l}\text { DE GRUYTER } \\
\text { OPEN }\end{array}$} & $\begin{array}{l}\text { HUNGARIAN JOURNAL OF } \\
\text { INDUSTRY AND CHEMISTRY }\end{array}$ & \multirow[t]{3}{*}{ 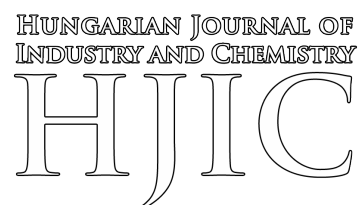 } \\
\hline & & Vol. 44(2) pp. 135-139 (2016) & \\
\hline & & $\begin{array}{l}\text { hjic.mk.uni-pannon.hu } \\
\text { DOI: } 10.1515 / \text { hjic-2016-0017 }\end{array}$ & \\
\hline
\end{tabular}

\title{
CHARACTERISATION OF CEMENTS FROM DOMINANTLY VOLCANIC RAW MATERIALS OF THE CARPATHIAN BEND ZONE
}

\author{
Timea Halmagyi, ${ }^{1}$ Emilia MosonyI, ${ }^{2}$ JÓzsef FAZeKas, ${ }^{2 *}$ Maria Spataru ${ }^{1}$ and FiRuta Goga ${ }^{2}$ \\ ${ }^{1}$ S.C. Valdek IMPEX SRL, Sfantu Gheorghe Str. 1 Decembrie 1918, BI. 15, Sc. E, Et. 3, Ap. 9., \\ Judetul Covasna, ROMANIA \\ 2 “Babes-Bolyai" University, Kogalniceanu Str. 1, 400082 Cluj-Napoca, ROMANIA
}

\begin{abstract}
This paper presents the results of laboratory investigations regarding the production of cements from local raw materials, such as limestone from Varghis, gypsum from Nucsoara, basaltic scoria from Racosul de Jos, volcanic tuff from Racosul de Sus, diatomite from Filia, and red mud from Oradea. The raw mixtures, based on modified Bogue calculations, contain limestone, gypsum, and one or two of the above-mentioned materials. The cements resulted from clinker grinding in a laboratory gas furnace at $1260-1300{ }^{\circ} \mathrm{C}$, with one hour at the peak temperatures, and were characterised for Blaine specific surface area, specific density, and mineral phases. Physico-mechanical properties, such as water content for normal consistency, setting time, soundness, and compressive strength were also determined. Results show that these cements contain belite, ferrite, calcium sulphoaluminate, anhydrite, and some minor compounds.
\end{abstract}

Keywords: experimental cement, Varghis limestone, Racosul de Sus volcanic tuff, setting time, mechanical properties

\section{Introduction}

Manufacturing of Portland cement is energy consuming, globally accounting for $2 \%$ of primary energy and $5 \%$ of industrial energy consumption. Moreover, Portland cement production contributes significantly to greenhouse gas emission in the order of $5 \%$ of the global $\mathrm{CO}_{2}$ emissions due to anthropogenic sources [1]. New civil engineering requirements impose the production of a new type of cement, which is of good quality, environmentally friendly, and requires low energy utilization. Low-energy cement manufacturing is economically and ecologically preferable. These cements could be used in places where high early strength or expansion compensation and also increased durability are required.

In cement chemistry, notation of oxides are abbreviated by their first capital letters: $\mathrm{C}=\mathrm{CaO}$, $\mathrm{S}=\mathrm{SiO}_{2}, \mathrm{~A}=\mathrm{Al}_{2} \mathrm{O}_{3}, \mathrm{~F}=\mathrm{Fe}_{2} \mathrm{O}_{3}, \mathrm{CS}=\mathrm{SO}_{3}$, and $\mathrm{H}=\mathrm{H}_{2} \mathrm{O}$. Lowenergy cements comprise those that belong to the $\mathrm{CaO}$ $\mathrm{SiO}_{2}-\mathrm{Al}_{2} \mathrm{O}_{3}-\mathrm{Fe}_{2} \mathrm{O}_{3}-\mathrm{CS}$ system. They are mainly sulphoaluminate belitic and sulphoferroaluminate belitic cements [2]. These can be produced from both natural raw materials or raw material mixtures, containing byproducts or industrial waste, by firing at lower temperatures than for Portland cement clinkers. A large variety of cements was developed in China based on the

*Correspondence: chemiceramic@gmail.com composition $\mathrm{C}_{4} \mathrm{~A}_{3} \overline{\mathrm{S}}$. These were standardized and named as "Third Cement Series" [3]. These cements have special features such as quick setting time, good impermeability, and rapid strength development even at low temperatures.

There are numerous investigations on the laboratory-scale production of sulphoaluminate belite (SAB) cement [4-18]. SAB cement can be classified into three major categories according to the content and proportions of the phase compositions. The tentative naming and some basic properties are summarized below:

1. Calcium sulphoaluminate-rich belite cement: They are mostly composed of only two main phases of SAB cement, the major components being $\mathrm{C}_{4} \mathrm{~A}_{3} \overline{\mathrm{S}}$ (around 55-75 $(\mathrm{g} / \mathrm{g}) \%$ ) and $\mathrm{C}_{2} \mathrm{~S}$. This type of cement is typically used for applications requiring rapid setting and high early strength $[4,6,8,9,19,20]$.

2. Expansive belite-rich calcium sulphoaluminate cements: Besides the main components of the SAB cements they contain free lime up to 10 $(\mathrm{g} / \mathrm{g}) \%$ which promotes expansion. This type of cement can be used in restricted areas requiring shrinkage-resistant and self-stressing cements $[4,12,16,20,21]$.

3. Non-expansive belite-rich calcium sulphoaluminate cements: These cements have higher belite, lower calcium sulphoaluminate, and much lower or completely deficient of free lime content than those of commercially produced SAB cements. Industrial by-products with high sulphate content can be used in high 
Table 1. Chemical compositions of the raw materials in $(\mathrm{g} / \mathrm{g}) \%$.

\begin{tabular}{lrrrrrr}
\hline oxides & $\begin{array}{c}\text { Varghis } \\
\text { limestone }\end{array}$ & $\begin{array}{r}\text { Oradea } \\
\text { red mud }\end{array}$ & $\begin{array}{c}\text { Racosul de Jos } \\
\text { basaltic scoria }\end{array}$ & $\begin{array}{c}\text { Racosul de Sus } \\
\text { volcanic tuff }\end{array}$ & $\begin{array}{c}\text { Filia } \\
\text { diatomite }\end{array}$ & $\begin{array}{c}\text { Nucsoara } \\
\text { gypsum }\end{array}$ \\
\hline $\mathrm{CaO}$ & 89.61 & 12.71 & 10.38 & 2.88 & 0.71 & 28.31 \\
$\mathrm{SiO}_{2}$ & 4.01 & 8.93 & 46.10 & 64.53 & 92.52 & 9.83 \\
$\mathrm{Al}_{2} \mathrm{O}_{3}$ & 5.16 & 17.04 & 18.78 & 11.80 & 3.24 & 2.73 \\
$\mathrm{Fe}_{2} \mathrm{O}_{3}$ & - & 48.37 & 9.93 & 2.57 & 2.18 & 1.07 \\
$\mathrm{Na}_{2} \mathrm{O}$ & - & 3.68 & 3.23 & 1.89 & - & 0.15 \\
$\mathrm{~K}_{2} \mathrm{O}$ & - & - & 1.69 & 2.75 & 0.46 & 0.55 \\
$\mathrm{MgO}$ & - & 1.30 & 7.21 & 0.45 & - & 0.39 \\
$\mathrm{TiO}_{2}$ & - & 6.80 & 1.61 & 0.27 & - & 0.13 \\
$\mathrm{~V}_{2} \mathrm{O}_{5}$ & - & 0.19 & - & - & - & 0.04 \\
$\mathrm{P}_{2} \mathrm{O}_{5}$ & 1.22 & 0.98 & 1.07 & - & - & 0.04 \\
$\mathrm{SO}_{3}$ & - & - & - & - & 0.89 & 37.08 \\
$\mathrm{Mn}_{2} \mathrm{O}_{3}$ & - & - & - & - & - & 0.02 \\
$\mathrm{P.C}$ & - & - & - & 12.40 & - & 19.90 \\
\hline
\end{tabular}

Table 2. Theoretical mineralogical and chemical compositions of the cements in $(\mathrm{g} / \mathrm{g}) \%$.

\begin{tabular}{ccccrcrrrr}
\hline \multirow{2}{*}{ Sample } & \multicolumn{3}{c}{ mineral composition } & \multicolumn{5}{c}{ oxidic compositions } \\
& $\mathrm{C}_{2} \mathrm{~S}$ & $\mathrm{C}_{4} \mathrm{~A}_{3} \overline{\mathrm{S}}$ & $\mathrm{C}_{4} \mathrm{AF}$ & $\mathrm{C} \overline{\mathrm{S}}$ & $\mathrm{CaO}$ & $\mathrm{Fe}_{2} \mathrm{O}_{3}$ & $\mathrm{SiO}_{2}$ & $\mathrm{Al}_{2} \mathrm{O}_{3}$ & \multicolumn{1}{c}{$\mathrm{SO}_{3}$} \\
\hline $\mathrm{C} 1, \mathrm{C} 2, \mathrm{C} 3$ & 56 & 12 & 22 & 10 & 55.15 & 7.23 & 19.53 & 10.63 & 7.46 \\
$\mathrm{C} 4$ & 50 & 18 & 15 & 17 & 53.11 & 4.93 & 17.44 & 12.17 & 12.36 \\
$\mathrm{C} 5$ & 43 & 28 & 23 & 6 & 51.38 & 7.56 & 15.00 & 18.86 & 7.20 \\
\hline
\end{tabular}

percentages in production. This type of cement shows high mechanical strength both at early and late ages comparable to ordinary Portland cement and has the potential to replace it $[4,6$, $8,14,16]$.

There is no commercial production of the beliterich calcium sulphoaluminate-type of cement. Mehta [18] produced $\mathrm{SAB}$ cements containing no free $\mathrm{CaO}$, but large amounts of belite rich in $\mathrm{CaCO}_{3}$, silicic acid, hydrated alumina, iron oxide, and gypsum. The clinkers were obtained by heating the raw materials in an electric muffle furnace at $1200{ }^{\circ} \mathrm{C}$ for about 1 hour. Clinkers were ground to a Blaine specific surface area of about $400 \mathrm{~m}^{2} \mathrm{~kg}^{-1}$.

Microstructure examinations of the clinkers showed that $\mathrm{C}_{4} \mathrm{~A}_{3} \overline{\mathrm{S}}$ appears as cubic crystals whereas belite appears as large rounded grains. The clinkers were very easy to grind due to their brittleness [4]. Sahu et alia [12] produced cements of Types 2 and 3 from limestone, fly ash and gypsum at $1200{ }^{\circ} \mathrm{C}$, for a bearing time of 30 minutes and cooled by fresh air. Kasselouri et alia [17] in 1995 obtained cement of Type 3 at 1280 ${ }^{\circ} \mathrm{C}$ from limestone, gypsum, bauxite, silica sand, and iron-rich industrial by-products. Cements composed from a mixture of baghouse dust, F-class fly ash, and scrubber sludge, sintered at $1175-1250{ }^{\circ} \mathrm{C}$ for bearing times of 30,45 , and 60 minutes, and cooled by natural air were obtained according to Arjunan et alia [10]. Mixtures composed of limestone, bottom ash, baghouse filter ash, bauxite, and gypsum fired at 1250 and 1300 ${ }^{\circ} \mathrm{C}$, for a bearing time of 60 minutes, lead to $\mathrm{SAB}$ cement of $\mathrm{C}_{4} \mathrm{~A}_{3} \overline{\mathrm{S}}$ - ye'elimite, $\mathrm{C}_{2} \mathrm{~S}$-larnite (belite), $\mathrm{C}_{4} \mathrm{AF}$-brownmillerite, and $\mathrm{C} \overline{\mathrm{S}}$ - anhydrite compositions [4]. The absence of tricalcium aluminate $\left(\mathrm{C}_{3} \mathrm{~A}\right)$ in these cements indicates that the decomposition of the desired mineral $\mathrm{C}_{4} \mathrm{~A}_{3} \overline{\mathrm{S}}$ does not take place at these temperatures. The presence of the desired minerals and the absence of $\mathrm{C}_{5} \mathrm{~S}_{2} \overline{\mathrm{S}}$ confirmed the formation of the $\mathrm{SAB}$ cement at $1250{ }^{\circ} \mathrm{C}$ and $1300{ }^{\circ} \mathrm{C}$ after 1 hour.

This article presents our study on the cement series sintered using local raw materials, such as volcanic tuffs from Racosul de Sus, basaltic scoria from Racosul de Jos, and diatomite from Filia (all in the Carpathian orocline), and red mud.

\section{Experimental}

The raw materials used for the cement experiments carried out as part of this study are natural (Varghis) limestone, Bodoc clay, Nucsoara gypsum, Racosul de Jos basaltic scoria, Racosul de Sus volcanic tuff, Filia diatomite, and artificial industrial waste (Oradea red mud). The selected raw materials were investigated for chemical compositions.

The chemical compositions of the limestone, red mud, diatomite, and basaltic scoria were analysed by SEM/EDAX. The volcanic tuff and gypsum analyses were performed by wet chemical methods, according to the SR EN 192-2 (Table 1). The theoretically estimated mineralogical, chemical compositions based on modified Bogue calculations [1, 4, 22] are given in Table 2. The compositions of the raw material mixtures are presented in Table 3. The raw material mixtures were obtained by grinding them in a laboratory ballmill up to a sieve residue of $90 \mu \mathrm{m}$ about $12 \%$. Afterwards, the raw material mixtures underwent a process of briquetting and drying followed by firing in a laboratory gas oven for one hour at a constant temperature of $1260-1300{ }^{\circ} \mathrm{C}$. The inside temperatures of the furnace were estimated with a thermocouple thermometer. Fast cooling was achieved in the air. The obtained cements from grinded clinkers (five hours in a mill, balls:clinkers ratio of 2:1) were tested. Mineralogical 
Table 3. The compositions of raw material mixtures in $(\mathrm{g} / \mathrm{g}) \%$.

\begin{tabular}{rrrrrrr}
\hline Samples & $\begin{array}{c}\text { Varghis } \\
\text { limestone }\end{array}$ & $\begin{array}{c}\text { Oradea } \\
\text { red mud }\end{array}$ & $\begin{array}{c}\text { Racosul de Jos } \\
\text { basaltic scoria }\end{array}$ & $\begin{array}{c}\text { Racosul de Sus } \\
\text { volcanic tuff }\end{array}$ & $\begin{array}{c}\text { Filia } \\
\text { diatomite }\end{array}$ & $\begin{array}{c}\text { Nucsoara } \\
\text { gypsum }\end{array}$ \\
\hline Cement 1 & 48.90 & - & 36.67 & - & - & 14.43 \\
Cement 2 & 54.08 & - & - & - & 13.70 & 32.22 \\
Cement 3 & 54.35 & - & - & 23.37 & - & 22.28 \\
Cement 4 & 54.66 & 0.98 & 31.53 & - & - & 12.83 \\
Cement 5 & 47.45 & 1.19 & 20.66 & - & - & 30.70 \\
\hline
\end{tabular}

Table 4. Mineral compositions in $(\mathrm{g} / \mathrm{g}) \%$ of the cement samples C1-C5 according to the IL-LAB-41 testing method.

\begin{tabular}{lrrrrr}
\hline \multicolumn{1}{c}{ Minerals } & \multicolumn{1}{c}{ C1 } & \multicolumn{1}{c}{ C2 } & \multicolumn{1}{c}{ C3 } & \multicolumn{1}{c}{ C4 } & \multicolumn{1}{c}{ C5 } \\
\hline Belite & 24.2 & 69.1 & 65.9 & 52.7 & 58.4 \\
Ferrite & 7.5 & 13.1 & 8.5 & 24.6 & 20.8 \\
Cubic aluminate & 8.5 & 0.4 & 0.0 & 0.2 & 4.7 \\
Orthorhombic aluminate & 20.5 & 0.0 & 0.0 & 1.5 & 0.0 \\
Free lime & 1.4 & 0.5 & 1.7 & 0.6 & 0.1 \\
Anhydrite & 2.1 & 6.8 & 3.8 & 1.5 & 5.3 \\
\hline
\end{tabular}

Table 5. Physical properties of cement samples C1-C5.

\begin{tabular}{ccrc}
\hline Sample & $\begin{array}{c}\text { Blaine specific } \\
\text { surface area, } \mathrm{cm}^{2} \mathrm{~g}^{-1}\end{array}$ & $\begin{array}{c}\text { Heat of } \\
\text { hydration, } \mathrm{J} \mathrm{g}^{-1}\end{array}$ & $\begin{array}{c}\text { Specific } \\
\text { density, } \mathrm{g} \mathrm{cm}^{-3}\end{array}$ \\
\hline $\mathrm{C} 1$ & 7367 & 29 & 3.17 \\
$\mathrm{C} 2$ & 8745 & 123 & 3.04 \\
$\mathrm{C} 3$ & 7963 & 32 & 3.07 \\
$\mathrm{C} 4$ & 6501 & 44 & 3.14 \\
$\mathrm{C} 5$ & 7553 & 110 & 3.26 \\
\hline
\end{tabular}

Table 6. Physico-mechanical properties of cement samples C1-C5.

\begin{tabular}{ccccccc}
\hline \multirow{2}{*}{ sample } & $\begin{array}{c}\text { water for normal } \\
\text { consistency, } \mathrm{cm}^{3}\end{array}$ & \multicolumn{2}{c}{ setting time, hour : minutes } & \multicolumn{2}{c}{ soundness, } & \multicolumn{2}{c}{ compressive strength, $\mathrm{N} \mathrm{mm}^{-2}$} \\
& early & final & $\mathrm{mm}$ & 2 days & 28 days \\
\hline C1 & 135 & $0: 44$ & $1: 44$ & 2.75 & 0.24 & 0.42 \\
C2 & 225 & $0: 13$ & $0: 35$ & 0.50 & 4.12 & 26.67 \\
C3 & 124 & $3: 35$ & $4: 29$ & 3.00 & 0.23 & 8.42 \\
C4 & 185 & $1: 57$ & $>10$ hour & 1.00 & 0.53 & 0.72 \\
C5 & 178 & $0: 05$ & $0: 15$ & 2.00 & 1.44 & 2.28 \\
\hline
\end{tabular}

compositions of cements made by XRD analyses with a Panalytical-Philips Cubix PRO X-ray spectrometer, according to IL LAB 41 proceedings are presented in Table 4. Experimental laboratory-produced cements were tested in conditions provided by the Romanian CRH CEMENT S.A. plant in Hoghiz (Brasov county). The Blaine specific surface area, specific density, heat of hydration (Table 5), volume of water for normal consistency, setting time, soundness, and compressive strength (Table 6) have been determined. Identification of mineral phases formed during the burning of clinkers was carried out by means of the Cubix PRO spectrometer.

\section{Results and Discussions}

The mineralogical compositions of the experimental cements are summarized in Table 4. All cement samples contain belite, ferrite, anhydrite, and many other phases in small amounts. The largest amount of belite found in a cement sample is in the raw mixture containing diatomite (sample $\mathrm{C} 2$ with $\mathrm{C}_{2} \mathrm{~S}=69.1 \%$ ), followed by the sample prepared with volcanic tuff (sample C3 with $\mathrm{C}_{2} \mathrm{~S}=65.9 \%$ ). Soner et alia reported [4] that the mineral $\mathrm{C}_{4} \mathrm{~A}_{3} \overline{\mathrm{S}}$ is stable between $1250-1350{ }^{\circ} \mathrm{C}$, but probably it can decompose during cooling. Furthermore, it was demonstrated that aluminium could be substituted by iron in the ye'elimite structure forming $\mathrm{C}_{4} \mathrm{~A}_{3-\mathrm{x}} \mathrm{F}_{\mathrm{X}} \overline{\mathrm{S}}[23-$ 26]. The experimental cement samples were characterized with regards to specific density and fineness, representing the Blaine specific surface area

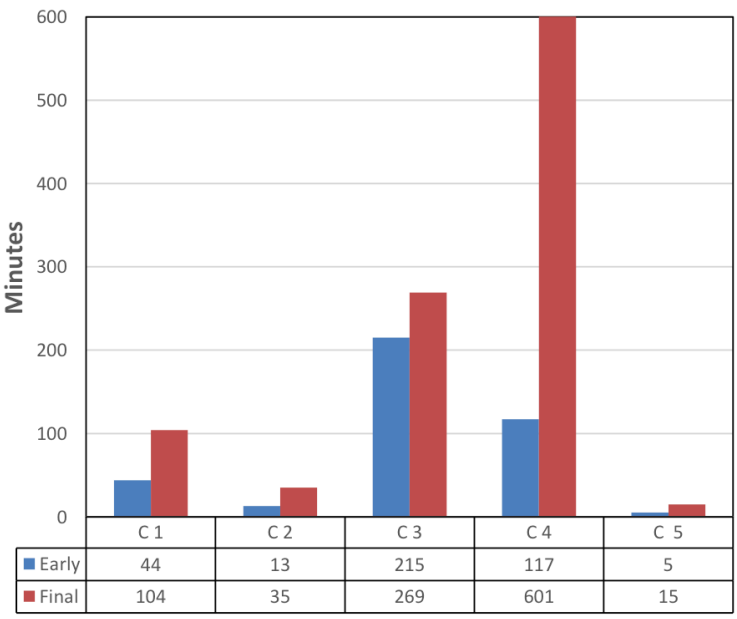

Figure 1. Early and final setting times of the cement samples in minutes.

[27]. The heat of hydration according was also determined to the SR EN 196-9/2006 method [28]. The physical properties of experimental cements are presented in Table 5.

The experimental Blaine fineness data are characterised by large specific surface areas. The biggest Blaine specific surface area was found in sample C2 (with diatomite) followed of sample C3 sample (with volcanic tuff). These samples have the smallest specific densities in the same order. The binding behaviour of the cements was estimated by measuring the setting time, volume of water for normal consistency, soundness, and compressive strengths (after second and twenty-eighth days). To determine the 


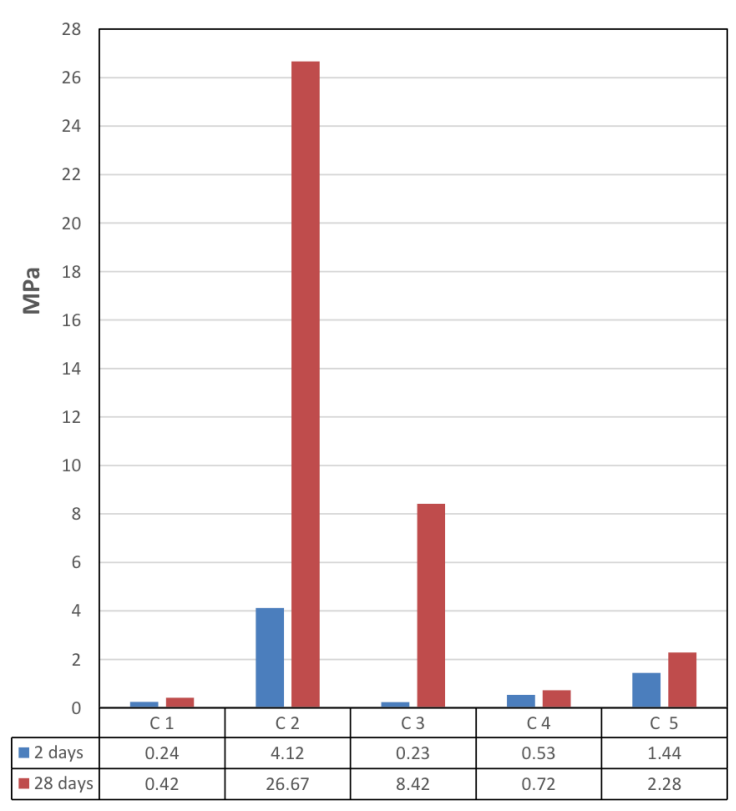

Figure 2. Compressive strength of cement samples after 2 and 28 days in MPa.

setting times, the quantity of water required to form cement paste of standard (normal) consistency was determined previously [29]. The water data for standard consistency are presented in Table 6. The setting time for the paste with standard consistency was measured using a Vicat device. The initial and final setting data of the investigated cements are also shown in Table 6 and Fig.1. The compressive strengths have been determined according to the SN EN-1/2006 method [30] and the data are shown in Fig.2.

The investigated cements exhibited different mechanical strengths, as a function of their mineral compositions. The strength of $\mathrm{SAB}$ cements depends mainly on the mineral ye'elimite $\left(\mathrm{Ca}_{4} \mathrm{Al}_{6} \mathrm{O}_{12} \mathrm{SO}_{4}\right.$ or $\mathrm{C}_{4} \mathrm{~A}_{3} \overline{\mathrm{S}}$ ) during the initial minutes up to hours of hydration [31, 32]. Ye'elimite is almost entirely responsible for the hydration reactions at early ages of CSA-type cements [23]. The presence of belite was found to be responsible for compressive strength at late ages. The compositions of raw material mixtures for these experimental cements influenced their mineral contents. Taking into consideration these, the initial strengths are better for the cements containing diatomite (sample C2), volcanic tuff (sample C3), basaltic scoria (sample C4), and red mud (sample C5). A higher content of red mud is favoured over sample C4 (see Tables 3 and 4,Fig.2).

A good evolution of mechanical strength over time is shown for samples C5 and especially for the C2 cements. C3 cement sample is also notable, but with lower initial strength, which is an important characteristic for a favourable evolution of specific surface area. This is clearly the largest value for cement sample C3. The cements containing basaltic scoria generally developed lower mechanical strengths in comparison to those containing diatomite or volcanic tuff. The cement containing diatomite is noticeable due to its very high initial strength (Table 6). For this cement, the compressive strength, after two days increased, which may be a consequence of the increased specific surface area. In terms of practical applications, the development of cement of good mechanical strength and workability depending on the setting time is of importance. The setting time of investigated cements was decisively influenced by the content of raw material mixtures (see Table 3). In the order of $\mathrm{C} 4 \rightarrow \mathrm{C} 3 \rightarrow \mathrm{C} 1 \rightarrow \mathrm{C} 2 \rightarrow \mathrm{C} 5$, the setting time becomes shorter. For the cement samples containing $1.2 \%$ red mud, 20.7\% basaltic scoria (C5) and $13.7 \%$ diatomite (C2), the setting time is quick. This is a consequence of rapid hydration processes. Because of this, these latter samples can be considered for practical applications only as retarding admixtures or super-plasticizers due to their set-retarding effect. Soundness shows reasonable values, which is required to be less than $10 \mathrm{~mm}$ for Portland cement.

\section{Conclusion}

Based on investigations into cement samples in the laboratory of the Hoghiz plant, it can be concluded that from all raw material mixtures, heated at temperatures of between 1260 and $1300{ }^{\circ} \mathrm{C}$, resultant clinkers contain more belite, ferrite, and anhydrite. Physico-mechanical properties show good compressive strength at early ages, good soundness, the biggest Blaine specific surface area $\left(S_{\mathrm{sp}}=8745 \mathrm{~cm}^{2} \mathrm{~g}^{-1}\right)$ for cement containing limestone, diatomite, and gypsum, as well as belite and anhydrite. The use of the local raw materials from the Carpathian orocline area, e.g. Varghis limestones, Bodoc clays, Nucsoara gypsum, volcanic tuffs from Racosul de Sus, basaltic scoria from Racosul de Jos, and Filia diatomite, facilitated the formation of cements that are more belitical than sulphoaluminate.

\section{Acknowledgement}

The authors are grateful to Chemi Ceramic SRL in Sfantu Gheorghe where the specific experimental cements were manufactured and to the Hoghiz plant where their physico-mechanical characteristics were tested.

\section{REFERENCES}

[1] Chen, I.A.: Synthesis of Portland cement and calcium sulfoaluminate-belite cement for sustainable development and performance, Ph.D. Dissertation, The University of Texas at Austin, 2009 www.lib.utexas.edu/etd/d/2009/cheni55279

[2] Jun-an, D.; De-dong, L.; Mu-zhen, S.; Jan-mon, $\mathrm{W}$.: A study of mineral composition of cement in the quinary system $\mathrm{CaO}-\mathrm{SiO}_{2}-\mathrm{Al}_{2} \mathrm{O}_{3}-\mathrm{Fe}_{2} \mathrm{O}_{3}-\mathrm{SO}_{3}, J$. Chin. Ceram. Soc. 1982 Article No. 4 en.cnki.com.cn/Article_en/CJFDTOTALGXYB198204000

[3] Zhang, L.; Su, M.; Wang, Y.: Development and use of sulpho- and ferro-aluminate cements in China, Adv. Chem. Res. 1999 1, 15-21 DOI: 10.1680/adcr.1999.11.1.15 
[4] Soner, I.: Utilization of fluidized bed combustion ashes as raw material in the production of a special cement, M.Sc. Dissertation, Middle East Technical University, Haziran, Turkey, June 2009 www.osti.gov/scitech/biblio/5635811

[5] Majling, J.; Roy, M.D.: The potential of fly ash for cement manufacture, Am. Ceram. Soc. Bull. 1993 72(10), 77-81 www.osti.gov/scitech/biblio/5635811

[6] Gartner, E.: Industrially interesting approaches to "Low- $\mathrm{CO}_{2}$ " cements, Cement Concrete Res. 2004 34, 1489-1498 DOI: 10.1016/j.cemconres.2004.01.021

[7] Quillin, K.: Performance of belite-sulfoaluminate cements, Cement Concrete Res. 2001 31, 13411349 DOI: $10.1016 / \mathrm{S} 0008-8846(01) 00543-9$

[8] Phair, W.J.: Green chemistry for sustainable cement production and use, Green Chem. 2006 8, 763-780 DOI: 10.1039/B603997A

[9] Zhou, Q.; Milestone, B.N.; Hayes, M.: An alternative to Portland cement for waste encapsulation - The calcium sulfoaluminate cement system, J. Hazard. Mat. 2006 136, 120-129 DOI: 10.1016/j.jhazmat.2005.11.038

[10]Arjunan, P.; Silsbee, R.M.; Roy, M.D.: Sulfoaluminate-belite cement from low-calcium fly ash and sulfur-rich and other industrial byproducts, Cement Concrete Res. 1999 29, 13051311 DOI: 10.1016/S0008-8846(99)00072-1

[11]Janotka, I.; Krajci, L.; Mojumdar, C.S.: Influence of Portland Cement Addition to Sulphoaluminate Belite Cement on Hydration and Mechanical Properties of Hardened Mortars, Ceramics-Silikaty 2002 46(3), 110-116 www.irsm.cas.cz/materialy/ cs_content/2002/Janotka_CS_2002_0000.pdf

[12] Sahu, S.; Majling, J.: Preparation of sulphoaluminate belite cement from fly ash, Cement Concrete Res. 1994 24(6), 1065-1072 DOI: 10.1016/0008-8846(94)90030-2

[13]Janotka, J.; Krajci, L.; Mojumdar, C.S.: Performance of sulphoaluminate-belite cements with high $\mathrm{C}_{4} \mathrm{~A}_{3}$ content, Ceramics-Silikaty 2007 51(2), 74-81 www.irsm.cas.cz/materialy/cs_content/2007/ Janotka_CS_2007_0000.pdf

[14] Adolfsson, D.; Menad, N.; Viggh, E.; Björkman, B.: Steelmaking slags as raw material for sulphoaluminate belite cement, Adv. Cement Res. 2007 19(4), 147-156 DOI: 10.1680/adcr.2007.19.4.147

[15]Popescu, D.C.; Muntean, M.; Sharp, H.J.: Industrial trial production of law energy belite cement, Cement Concrete Composites 2003 25, 689-693 DOI: 10.1016/S0958-9465(02)00097-5

[16] Katsioti, M.; Tsakiridis, E.P.; Leonardou-Agatzini, S.; Oustadakis, P.: Examination of the jarositealunite precipitate addition in the raw meal for the production of sulfoaluminate cement clinker, $J$. Hazard. Mat. 2006 131(1-3), 187-194 DOI: 10.1016/j.jhazmat.2005.09.028

[17] Kasselouri, V.; Tsakiridis, P.; Malami, C.; Georgali, B.; Alexandridou, C.: a study on the hydration products of a non-expansive sulfoaluminate cement, Cement Concrete Res. 1995 25(8), 1726-1736 DOI: $10.1016 / 0008$ 8846(95)00168-9
[18] Mehta, K.P.: Investigations on energy-saving cements, World Cement Technol. 1980 11(5), 166177

[19]Zhang, L.; Glasser, P.F.: Hydration of calcium sulfoaluminate cement in less than $24 \mathrm{~h}, A d v$. Cement Res. 2002 14(4), 141-155 DOI: 10.1680/adcr.2002.14.4.141

[20] Uchikawa, H.: Management strategy in cement technology for the next century Part 3, World Cement 1994 VOL(11), 47-54

[21] Teoreanu, I.; Muntean, M.: Expansive sulphate aluminate cements, Cement Concrete Res. 1983 13, 711-720

[22]Dan, E.: The low energy cements durability, manufactured with addition of industrial waste materials, Ph.D. Thesis (University Politehnica Bucharest, Bucharest, ROMANIA) 2004 (in Romanian)

[23] Bullerjahn, F.; Haka, M.B.; Scrivener, K.: Iron solid solutions of ye'elimite-effect on reactivity, Proc. $19^{\text {th }}$ Int. Building Material Expo (Weimar, Germany) 2015 researchgate.net/publication/282356671

[24] Cuesta, A.; Álvarez-Pinazo, G.; Sanfélix, S.G.; Peral, I.; Aranda, M.A.G.; De la Torre, A.G.: Hydration mechanisms of two polymorphs of synthetic ye'elimite, Cement Concrete Res. 2014 63, 127-136 DOI: 10.1016/j.cemconres.2014.05.010

[25] Idrissi, M.; Diour, A.; Damidot, D.; Greneche, J.M.; Alami Talbi, M.; Taibi M.: Characterisation of Iron Inclusion during the Formation of Calcium Sulfoaluminate Phase, Cement Concrete Res. 2010 40(8), 1314-1319 DOI: 10.1016/j.cemconres.2010.02.009

[26]Pöllmann, H.; Stöber, S.; Schmidt, R.: Synthesis and characterization of sulfoaluminate (belite) cements from industrial residues, Proc. $1^{\text {st }}$ Int. Conf. on Sulphoaluminate Cement: Mat. Engng. Technol (Wuhan University of Technology Press, Wuhan, China) pp. 366-384, 2013 www.irsm.cas.cz/ materialy/cs_content/2013/Ma_CS_2013_0000.pdf

[27] SR EN Standard 196-6: Method of testing cement Part 6: Determination of blaine specific surface area and specific density, 2006 tpm.fsv.cvut.cz/ student/documents/files/BUM1/Chapter12.pdf

[28] SR EN Standard 196-9: Method of testing cement Part 9: Determination of the heat of hydration, 2006 tpm.fsv.cvut.cz/student/documents/files/BUM1/Chapter12.pdf

[29] SR EN Standard 196-3: Method of testing cement Part 3: Determination of setting time and le chatelier soundness, 2006 tpm.fsv.cvut.cz/student/ documents/files/BUM1/Chapter12.pdf

[30] SR EN Standard 196-1: Method of Testing Cement - Part 1: Determination of Strength, 2006

[31]Zhang, L.; Su, M.; Wang, Y.: Development and use of sulfo- and ferro-aluminate cements in China, Adv. Cement Res. 1999 1, 15-21 DOI: 10.1680/adcr.1999.11.1.15

[32] Winnefeld, F.; Barlag, S.: Calorimetric and thermogravimetric study on the influence of calcium sulfate on the hydration of ye'elimite, $J$. Therm. Anal. Calorimet. 2009 101(3), 949-957 DOI: 10.1007/s10973-009-0582-6 